\title{
Effect of timing and graded levels of nitrogen and potassium in SRI cultivation
}

\author{
S. Sivagnanam ${ }^{1 *}$, K. Arivazhagan ${ }^{2}$, V. Arunkumar ${ }^{3}$ and S. Natarajan ${ }^{4}$ \\ ${ }^{1}$ Department of Soil Science and Agricultural Chemistry, Tamil Nadu Agricultural University, Coimbatore - 641003, \\ INDIA \\ ${ }^{2}$ Department of Soil Science and Agricultural Chemistry, Faculty of Agriculture, Annamalai University, Annamalai \\ Nagar - 608 002, INDIA \\ ${ }^{3}$ Department of Soil Science and Agricultural Chemistry, Agricultural collage and Research Institute, Tamil Nadu \\ agricultural University, Killiculam - 628252, INDIA \\ ${ }^{4}$ Department of Agronomy, Faculty of Agriculture, Annamalai University, Annamalai Nagar - 608 002, INDIA \\ *Corresponding author. E-mail: sivagri@gmail.com
}

Received: September 1, 2014; Revised received: July 3, 2015; Accepted: July 31, 2015

\begin{abstract}
A field experiment was carried out at Annamalai University Experimental farm, Annamalai nagar, during Kuruvai and Navarai in the year 2008-09. To study the timing and graded levels of nitrogen and potassium in rice crop under SRI (System of rice intensification) cultivation. The experiment was laid out on deep clay soil by adopting randomized block design with factorial technique (FRBD). The results of field experiment revealed that the maximum growth and yield attributes were recorded in the treatment which received $\mathrm{P}_{2} \mathrm{O}_{5}$ as fully basal dose and nitrogen as three split doses viz., $50 \%$ basal and $25 \%$ each at tillering and panicle initiation stages. Potassium was applied as $33.3 \% \mathrm{~K}_{2} \mathrm{O}$ each at 15,30 and 45 DAT. This treatment significantly recorded higher grain yield of $6278.7 \mathrm{~kg} \mathrm{ha}^{-1} \mathrm{in}$ field experiment $-\mathrm{I}$ and $6577.9 \mathrm{~kg} \mathrm{ha}^{-1}$ in field experiment - II; and the straw yield of 7010.3 and $7309.7 \mathrm{~kg} \mathrm{ha}^{-1}$ in field experiment I and II respectively. The shoot and grain uptake of nutrients (N, P and K) were high during 15,30 and 45 DAT and at harvest which received $33.3 \% \mathrm{~K}_{2} \mathrm{O}$ each at 15,30 and 45 DAT.
\end{abstract}

Keywords: Graded levels, Nutrient uptake, Nitrogen, Potassium, SRI

\section{INTRODUCTION}

Rice is the one of the staple food grain crop for more than half of the world's population. It provides $60-70$ $\%$ of body calories intake of the consumers (FAO, 2003). India rank first in productive land about 45 million hectares $(\mathrm{M}$ ha) and second in production about 88 million tones (Mt) next only China in the world. The system of rise intensification (SRI) is one of the new methodologies for increasing yield (Productivity) of irrigated rice crop. The SRI cultivation uses of much less irrigation, seed rate and fertilizer applications compare to the traditional rice cultivation practices (Janitha, 2007).

Nitrogen is the most improtent element which impacts yield and quality in crops (Cassman et al. 2002; Shanahan e tal. 2008). That has profound effect on growth and yield of rice with the total fertilizer $\mathrm{N}$ consumption of about $12 \mathrm{Mt}$. (IASRI, 2003). Currently nitrogen fertilizer is often applied in excess of crop needs, resulting in economic loss and environmental pollution ( $\mathrm{Ju}$ et al. 2009). Therefore, precision management of crop $\mathrm{N}$ status is important, and real time and precise evaluation of crop $\mathrm{N}$ status in the field was proved to be an effective way to improve $\mathrm{N}$ use efficiency, crop yield and quality (Raun et al., 2002). Potassium has an important role in enzyme activation, especially Rubiso activity, protein synthesis and the establishment of trasmembrane $\mathrm{pH}$ and electric charge gradients. Insufficient $\mathrm{K}^{+}$supply to plants leads to growth retardation and old leaves become chlorotic and necrotic (Marschner, 1995; Mengel, 2007). K is attracting more and more attention fallowing the increased application of $\mathrm{N}$ and $\mathrm{P}$ fertilizers and use of high yielding varieties. Manzoor et al. (2008) reported that the problem of $\mathrm{K}$ fixation can be reduced to some extent and efficiency may be improved by different $\mathrm{K}$ application methods. The sources of $\mathrm{K}$ and their time of application may also affect the $\mathrm{K}$ recovery. $\mathrm{K}$ is vital to the process of photosynthesis. It reduces $\mathrm{N}$ losses by inhibiting denitrification. $\mathrm{K}$ concentration can influence the permeability of crops (Janitha, 2007). Arivazhagan and Ravichandran (2005) reported that in general, nutrient uptake, grain and straw yields increased with increased levels of $\mathrm{N}$ and $\mathrm{K}$.

Rice (Oryza sativa) is a cereal grain of the grass family (Graminae) probably it is native to the atlas of the great Asian rivers- the Ganges, the Chang (Yuangtze) and the Tigris and Euphrates. Rice, one of the most important food crops in the world, forms the staple diet 
of 2.7 billion people. It is grown in all the continents except Antartica, occupying 150 million ha and producing 573 million tones paddy with an average productivity of 3.83 ton / ha. Rice provides $32-59 \%$ of the dietary energy and $25-44 \%$ of the dietary protein in 39 (Janitha, 2007).

In India, it accounts for more than $40 \%$ of food grain production. One of the way to solve the water crisis for rice cultivation may be the System of rice intensification (SRI) developed in the early 1980s in Madagascar by Fr. Henri de Laulanie has undergoing some changes within the country and in other countries as the basic SRI methodology gets introduced and evaluated. SRI is otherwise called as "Aerobic rice cultivation" and in Tamil it is called as "Semmai Nel-Sagupadi". Vijay Kumar et al., Studied the yield attributes, yield and water productivity of rice under SRI cultivation. The grain yield, water productivity were significantly increased when following SRI with 14 days old seedlings planted at $25 \times 25 \mathrm{~cm}$ spacing to achieve the yield. Hence, the field investigation was carried out with the different timing and levels of $\mathrm{N}$ and $\mathrm{K}$ application on the growth and yield attributes, nutrient uptake of grain and straw in SRI cultivation.

\section{MATERIALS AND METHODS}

The field experiments were conducted during Navarai (January - April 2008) and Kuruvai (June-September 2008) seasons. The experiments were conducted in the field of wetland block of experimental farm, Annamalai University, Annamalainagar. The experimental farm is geographically located at $11^{\circ} 24^{\prime} \mathrm{N}$ latitude and $79^{\circ} 41^{\prime} \mathrm{E}$ longitude at an altitude of $+5.79 \mathrm{~m}$ above mean sea level and $6 \mathrm{~km}$ away from Bay of Bengal. The soil of experiment field was deep moderately drained, clay in texture with $\mathrm{pH}(8.19)$ and EC (0.96 $\left.\mathrm{dSm}^{-1}\right)$. The soil is medium in available nitrogen (348 $\left.\mathrm{kg} \mathrm{ha}^{-1}\right)$, medium in available phosphorus $\left(13 \mathrm{~kg} \mathrm{ha}^{-1}\right)$ and high in available potassium (448 $\left.\mathrm{kg} \mathrm{ha}^{-1}\right)$. Experiments were laid out in a randomized block design (FRBD) with factorial technique and three replications. Three different fertilizer doses viz., 90:38:28.5 ( $\left.\mathrm{F}_{1}\right)$, 120:38:38 $\left(\mathrm{F}_{2}\right)$ and 150:38:47.5 $\left(\mathrm{F}_{3}\right) \mathrm{kg} \mathrm{N}, \mathrm{P}_{2} \mathrm{O}_{5}$ and $\mathrm{K}_{2} \mathrm{O}$ ha $^{-1}$ was applied according to the treatment schedule. Phosphorus was applied fully as basal dose and nitrogen as three split doses viz., $50 \%$ at basal $25 \%$ at tillering and remaining $25 \%$ at panicle initiation stage. The treatment $\left(\mathrm{T}_{2}\right)$ which received $50 \% \mathrm{~K}_{2} \mathrm{O}$ as basal and the remaining $50 \% \mathrm{~K}_{2} \mathrm{O}$ split into two equal halves and applied at 20 DAT (days after transplanting) and 40 DAT. The treatment $\left(\mathrm{T}_{3}\right)$ which received $33.3 \% \mathrm{~K}_{2} \mathrm{O}$ as basal and the remaining $66.6 \%$ $\mathrm{K}_{2} \mathrm{O}$ split into two equal halves and applied at 20 DAT and 40 DAT. In the rest of the treatments basal skipping of $\mathrm{K}_{2} \mathrm{O}$ was followed and applied in 50\% $\mathrm{K}_{2} \mathrm{O}$ at 20 DAT and remaining $50 \% \mathrm{~K}_{2} \mathrm{O}$ at 40 DAT $\left(\mathrm{T}_{4}\right)$ and in the treatment $\left(\mathrm{T}_{5}\right)$ each of $33.3 \% \mathrm{~K}_{2} \mathrm{O}$ applied at 15 DAT, 30 DAT and 45 DAT. The treatment
$\mathrm{T}_{1}$ is absolute control. The $\mathrm{N}, \mathrm{P}_{2} \mathrm{O}_{5}$ and $\mathrm{K}_{2} \mathrm{O}$ were applied through urea, superphosphate and muriate of potash, respectively.

\section{RESULTS AND DISCUSSION}

Growth, yield and yield attributes: The studies on the influence of different levels of nitrogen and potassium applied at different time intervals of SRI cultivation revealed that, number of panicle hill ${ }^{-1}$, panicle length, number of filled grain panicle ${ }^{-1}$ and one thousand grain weight. The treatment which received $50 \% \mathrm{~N}$ basal and $25 \%$ each at tillering and panicle initiation stages and 33.3\% $\mathrm{K}_{2} \mathrm{O}$ applied @ 15 DAT, 30 DAT and 45 DAT (basal skipping of $\mathrm{K}_{2} \mathrm{O}$ ) was significantly increased the panicle length $(19.30 \mathrm{~cm})$, One thousand grain weight $(20.76 \mathrm{~g})$ and number of filled grain panicle hill ${ }^{-1}$ (159) (Table 1). The usefulness of increased $\mathrm{N}$ application on tiller production was also increased by Singh et al. (2006). Split application of potassium with nitrogen was more effective in improving the yield attributing characters. This corroborates with the finding of Mondal et al. (1989) and Venkitaswamy et al. (1997). Under SRI cultivation the total number of panicles and their individual grain sizes, consequently total grain yield are potentially increased (Uphoff et al., 2002; Stoop, 2003).

The effect of different levels of nitrogen and potassium applied at different time intervals on the yield attributes of the SRI cultivation significantly increased the grain and straw yield. The treatment which received each of $33.3 \% \mathrm{~K}_{2} \mathrm{O}$ at 15 DAT, 30 DAT and 45 DAT (basal skipping of $\mathrm{K}_{2} \mathrm{O}$ ) was significantly incr eased the grain and straw yield. The highest grain and straw yield was recorded in field experiment I and II (6278 and $7010.3 \mathrm{Kg} \mathrm{ha}^{-1}$ ) (Fig. 1 and 2) and (6577.9 and $7309.7 \mathrm{Kg} \mathrm{ha}^{-1}$ ) (Table 2). Basal skipping of $\mathrm{K}$ and application of $33.35 \mathrm{~K}_{2} \mathrm{O}$ at $15 \mathrm{DAT}, 30 \mathrm{DAT}$ and 45 DAT significantly increased the grain yield as compare to basal application and top dressing. This may be due to higher nutrient availability, growth and yield parameters at different stage of crop growth and ultimately the grain yield. Samrathlal et al. (2003) claimed that grain and straw yields of rice crop were increased significantly owing to potash fertilization in two equal splits. Ali et al., (2005) recorded that among the different methods and time of potash application treatments, maximum paddy yield was obtained from the treatments of basal skiping of potassium. Awan et al. (2007) while performing field experiments across six districts of Punjab concluded that potash application at two splits resulted in more number of grains panicle ${ }^{-1}$, highest 1000 grain weight and maximum paddy yield. Ravichandran and. Sriramachandrasekharan (2011) also reported the similar result was basal skipping of $\mathrm{K}_{2} \mathrm{O}$ and application of entire quantity of $\mathrm{K}_{2} \mathrm{O}$ into two equal splits resulted in higher growth, grain and straw yields of rice in both kharif and rabi seasons. 
Table 1. Effect of graded levels and timing of nitrogen and potassium application on panicle length (cm), One thousand grain

\begin{tabular}{|c|c|c|c|c|c|c|c|c|c|c|c|c|}
\hline \multirow{2}{*}{$\begin{array}{c}\text { Fertil- } \\
\text { izer } \\
\text { schedule } \\
\text { Treatme } \\
\text { nt No. }\end{array}$} & \multicolumn{4}{|c|}{ Panicle length (cm) } & \multicolumn{4}{|c|}{ Thousand grain weight (g) } & \multicolumn{4}{|c|}{$\begin{array}{c}\text { Number of filled grains pani- } \\
\text { cle }^{-1}\end{array}$} \\
\hline & $\mathbf{F}_{1}$ & $\mathbf{F}_{2}$ & $\mathbf{F}_{3}$ & $\begin{array}{c}\text { Mea } \\
\mathbf{n}\end{array}$ & $\mathbf{F}_{1}$ & $\mathbf{F}_{2}$ & $\mathbf{F}_{3}$ & $\begin{array}{c}\text { Mea } \\
\mathbf{n}\end{array}$ & $\mathbf{F}_{1}$ & $\mathbf{F}_{2}$ & $\mathbf{F}_{3}$ & $\begin{array}{c}\text { Mea } \\
\mathbf{n}\end{array}$ \\
\hline $\mathrm{T}_{1}$ & 16.6 & 17.1 & 17.2 & 16.9 & 20.0 & 20.1 & 20.2 & 20.1 & 79 & 82 & 83 & 81.3 \\
\hline $\mathrm{T}_{2}$ & 17.0 & 19.2 & 19.3 & 18.5 & 20.80 & 20.82 & 20.84 & 20.80 & 155 & 167 & 175 & 165.6 \\
\hline $\mathrm{T}_{3}$ & 17.2 & 19.5 & 19.6 & 18.8 & 20.81 & 20.83 & 20.85 & 20.83 & 159 & 169 & 177 & 168.3 \\
\hline $\mathrm{T}_{4}$ & 17.5 & 19.9 & 20.0 & 19.1 & 20.87 & 20.84 & 20.86 & 20.84 & 162 & 170 & 180 & 170.6 \\
\hline $\mathrm{T}_{5}$ & 17.9 & 20.2 & 20.4 & 19.5 & 20.83 & 20.85 & 20.87 & 20.87 & 164 & 172 & 182 & 172.6 \\
\hline \multirow[t]{2}{*}{ Mean } & 17.2 & 19.2 & 19.3 & 18.6 & 20.64 & 20.70 & 20.75 & 20.75 & 143.8 & 152 & 159 & 151.7 \\
\hline & \multicolumn{2}{|c|}{$\mathrm{SE}_{\mathrm{D}}$} & \multicolumn{2}{|c|}{$\mathrm{CD}(\mathrm{P}=0.05)$} & \multicolumn{2}{|c|}{$\mathrm{SE}_{\mathrm{D}}$} & \multicolumn{2}{|c|}{$\mathrm{CD}(\mathrm{P}=0.05)$} & \multicolumn{2}{|c|}{$\mathrm{SE}_{\mathrm{D}}$} & \multicolumn{2}{|c|}{$\mathrm{CD}(\mathrm{P}=0.05)$} \\
\hline $\mathrm{F}$ & \multicolumn{2}{|c|}{0.10} & \multicolumn{2}{|c|}{0.20} & \multicolumn{2}{|c|}{ NS } & \multicolumn{2}{|c|}{ NS } & \multicolumn{2}{|c|}{1.32} & \multicolumn{2}{|c|}{2.72} \\
\hline $\mathrm{T}$ & \multicolumn{2}{|c|}{0.13} & \multicolumn{2}{|c|}{0.26} & \multicolumn{2}{|c|}{ NS } & \multicolumn{2}{|c|}{ NS } & \multicolumn{2}{|c|}{1.71} & \multicolumn{2}{|c|}{3.51} \\
\hline $\mathrm{F} \times \mathrm{T}$ & \multicolumn{2}{|c|}{0.22} & \multicolumn{2}{|c|}{0.46} & \multicolumn{2}{|c|}{ NS } & \multicolumn{2}{|c|}{ NS } & \multicolumn{2}{|c|}{2.97} & \multicolumn{2}{|c|}{6.08} \\
\hline
\end{tabular}

F: Factors; T: Treatments

Table 2. Effect of graded levels and timing of nitrogen and potassium application on grain yield and straw yield $\left(\mathrm{kg} \mathrm{ha}^{-1}\right)$ in SRI cultivation (Field experiment - II).

\begin{tabular}{|c|c|c|c|c|c|c|c|c|}
\hline \multirow{2}{*}{$\begin{array}{c}\text { Fertilizer } \\
\text { schedule } \\
\text { Treat- } \\
\text { ment No. }\end{array}$} & \multicolumn{4}{|c|}{ Grain yield $\mathrm{Kg} \mathrm{ha}^{-1}$} & \multicolumn{4}{|c|}{ Straw yield $\mathrm{Kg} \mathrm{ha}^{-1}$} \\
\hline & $\mathbf{F}_{1}$ & $\mathbf{F}_{2}$ & $\mathbf{F}_{3}$ & Mean & $\mathbf{F}_{1}$ & $\mathbf{F}_{2}$ & $\mathbf{F}_{3}$ & Mean \\
\hline $\mathrm{T}_{1}$ & 2897.2 & 2909.2 & 3020.9 & 2942.4 & 3519.9 & 4690.2 & 4751.2 & 4320.4 \\
\hline $\mathrm{T}_{2}$ & 5398.1 & 5787.4 & 5791.3 & 5658.9 & 5402.2 & 7257.5 & 7451.5 & 6703.7 \\
\hline $\mathrm{T}_{3}$ & 5507.5 & 5901.6 & 5918.7 & 5775.9 & 5688.5 & 7500.9 & 7631.5 & 6940.3 \\
\hline $\mathrm{T}_{4}$ & 5857.8 & 6133.6 & 6151.7 & 6047.7 & 5997.5 & 7579.5 & 7797.5 & 7124.9 \\
\hline $\mathrm{T}_{5}$ & 5988.2 & 6864.3 & 6881.2 & 6577.9 & 6280.9 & 7740.5 & 7907.9 & 7309.7 \\
\hline \multirow[t]{2}{*}{ Mean } & 5129.7 & 5519.2 & 5552.7 & 5400.5 & 5377.8 & 6953.7 & 7107.9 & 6479.8 \\
\hline & \multicolumn{2}{|c|}{$\mathrm{SE}_{\mathrm{D}}$} & \multicolumn{2}{|c|}{$\mathrm{CD}(\mathrm{P}=0.05)$} & \multicolumn{2}{|c|}{$\mathrm{SE}_{\mathrm{D}}$} & \multicolumn{2}{|c|}{$\mathrm{CD}(\mathrm{P}=0.05)$} \\
\hline $\mathrm{F}$ & \multicolumn{2}{|c|}{45.2} & \multicolumn{2}{|c|}{92.7} & \multicolumn{2}{|c|}{20.3} & \multicolumn{2}{|c|}{41.6} \\
\hline $\mathrm{T}$ & \multicolumn{2}{|c|}{58.4} & \multicolumn{2}{|c|}{119.7} & \multicolumn{2}{|c|}{26.2} & \multicolumn{2}{|c|}{53.8} \\
\hline $\mathrm{F} \times \mathrm{T}$ & \multicolumn{2}{|c|}{101.2} & \multicolumn{2}{|c|}{207.4} & \multicolumn{2}{|c|}{45.5} & \multicolumn{2}{|c|}{93.2} \\
\hline
\end{tabular}

F: Factors; T: Treatments

Nutrient uptake: The highest shoot and grain uptake was obtained in basal skipping of $\mathrm{K}_{2} \mathrm{O}$ and application of $33.3 \% \mathrm{~K}_{2} \mathrm{O}$ each at 15,30 and 45 DAT. The present finding corroborates with the result of Arivazhagan (1999) in rice Var. IR 20 and Janitha (2007) in rice Var. ADT 36. Fertilizer $\mathrm{N}$ was applied with 50 per cent as basal and the remaining 50 per cent in two equal splits at active tillering and panicle initiation stages of rice crop. Such situation of comfortable level of instantly usable nitrogen favors optimum nitrogen uptake by rice crop at different growth stage (Radha Kumar and Srinivasulu et al., 2009). The total uptake of nutrient is the product of its concentration. Split application of $\mathrm{K}$ resulted in higher nutrient uptake ( $\mathrm{N}, \mathrm{P}$ and $\mathrm{K}$ ) in shoot and grain as compared to basal application. This might be due to the efficient absorption and translocation of nutrients from soil to foliage. Inherent limitation associated with fully application at the time of transplanting viz. dilution, penetration and fixation was efficiently circumvented by split application (Majumdar and Ghosh, 1980). Among the fertilizer schedules tried, the highest mean value of $\mathrm{N}(36.9 \mathrm{~kg}$ ha ${ }^{1}$ ) in shoot uptake was observed in $\mathrm{F}_{3}(150: 38: 47.5 \mathrm{~N}, \mathrm{P}$ and $\mathrm{K}_{2} \mathrm{O} \mathrm{kg}$ ha-1) followed by $\mathrm{F}_{2}(120: 38: 38 \mathrm{~N}, \mathrm{P}$ and $\mathrm{K}_{2} \mathrm{O} \mathrm{kg}$ ha-1) and $\mathrm{F}_{1}\left(90: 38: 28.5 \mathrm{~N}, \mathrm{P}\right.$ and $\mathrm{K}_{2} \mathrm{O} \mathrm{kg}$ ha-1) (Table 3). Increase in grain $\mathrm{N}\left(59.5 \mathrm{~kg}\right.$ ha- $\left.^{1}\right), \mathrm{P}(14.6 \mathrm{~kg}$ ha$\left.{ }^{1}\right)$ and $\mathrm{K}\left(14.1 \mathrm{~kg} \mathrm{ha-}{ }^{1}\right)$ nutrient uptake was observed in $\mathrm{T}_{5}$ which received $33.3 \% \mathrm{~K}_{2} \mathrm{O}$ each at 15,30 and 45 DAT (Table 4). This may be due to the favorable possible interaction of $\mathrm{N}$ and $\mathrm{K}$ and the nutrient availability of more nutrients at critical stages of crop growth. Stoop et al, (2002) suggested that SRI practice develops deeper and stronger root system due to intermittent irrigation practices on soils without physical barriers on soils to root growth, planting of young seedling at wider spacing and application of slow releasing nutrient source such as compost.

\section{Conclusion}

The present study concluded that the System of Rice Intensification (SRI) method is effective, when 
Table 3. Effect of graded levels and timing of nitrogen and potassium on shoot nitrogen uptake $\left(\mathrm{Kg} \mathrm{ha}^{-1}\right)$ at tillering, panicle initiation and harvest stages in SRI cultivation.

\begin{tabular}{|c|c|c|c|c|c|c|c|c|c|c|c|c|}
\hline \multirow{2}{*}{$\begin{array}{c}\text { Fertilizer } \\
\text { Schedule } \\
\text { Treatment } \\
\text { No. }\end{array}$} & \multicolumn{4}{|c|}{ Tillering } & \multicolumn{4}{|c|}{ Panicle initiation } & \multicolumn{4}{|c|}{ Harvest stage } \\
\hline & $F_{1}$ & $\mathbf{F}_{2}$ & $\mathbf{F}_{3}$ & Mean & $F_{1}$ & $F_{2}$ & $F_{3}$ & Mean & $F_{1}$ & $F_{2}$ & $\mathbf{F}_{3}$ & Mean \\
\hline $\mathrm{T}_{1}$ & 16.53 & 16.50 & 16.53 & 16.51 & 25.33 & 23.60 & 25.06 & 24.66 & 28.17 & 28.40 & 28.64 & 28.40 \\
\hline $\mathrm{T}_{2}$ & 17.32 & 18.37 & 19.14 & 18.27 & 29.46 & 25.46 & 32.80 & 29.24 & 36.70 & 38.57 & 39.84 & 38.37 \\
\hline $\mathrm{T}_{3}$ & 17.52 & 18.94 & 19.66 & 18.70 & 30.80 & 27.06 & 34.00 & 30.62 & 37.41 & 38.96 & 40.32 & 38.89 \\
\hline $\mathrm{T}_{4}$ & 17.78 & 19.10 & 20.68 & 19.18 & 32.00 & 228.4 & 35.20 & 31.86 & 38.02 & 39.26 & 40.53 & 39.27 \\
\hline $\mathrm{T}_{5}$ & 17.98 & 19.34 & 21.86 & 19.72 & 33.20 & 29.60 & 36.80 & 33.20 & 38.29 & 40.46 & 40.78 & 39.84 \\
\hline \multirow[t]{2}{*}{ Mean } & 17.42 & 18.43 & 19.57 & 18.47 & 30.15 & 26.82 & 32.77 & 29.91 & 35.71 & 37.13 & 38.02 & 36.95 \\
\hline & \multicolumn{2}{|c|}{$\mathrm{SE}_{\mathrm{D}}$} & \multicolumn{2}{|c|}{$\mathrm{CD}(\mathrm{P}=0.05)$} & \multicolumn{2}{|c|}{$\mathrm{SE}_{\mathrm{D}}$} & \multicolumn{2}{|c|}{$\mathrm{CD}(\mathrm{P}=0.05)$} & \multicolumn{2}{|c|}{$\mathrm{SE}_{\mathrm{D}}$} & \multicolumn{2}{|c|}{$\mathrm{CD}(\mathrm{P}=0.05)$} \\
\hline $\mathrm{F}$ & \multicolumn{2}{|c|}{0.028} & \multicolumn{2}{|c|}{0.058} & \multicolumn{2}{|c|}{0.17} & \multicolumn{2}{|c|}{0.34} & \multicolumn{2}{|c|}{0.39} & \multicolumn{2}{|c|}{0.081} \\
\hline $\mathrm{T}$ & \multicolumn{2}{|c|}{0.037} & \multicolumn{2}{|c|}{0.075} & \multicolumn{2}{|c|}{0.22} & \multicolumn{2}{|c|}{0.45} & \multicolumn{2}{|c|}{0.051} & \multicolumn{2}{|c|}{0.104} \\
\hline $\mathrm{F} \times \mathrm{T}$ & \multicolumn{2}{|c|}{0.064} & \multicolumn{2}{|c|}{0.131} & \multicolumn{2}{|c|}{0.38} & \multicolumn{2}{|c|}{0.78} & \multicolumn{2}{|c|}{0.088} & \multicolumn{2}{|c|}{0.181} \\
\hline
\end{tabular}

F: Factors; T: Treatments

Table 4. Effect of graded levels and timing of nitrogen and potassium on grain nitrogen, phosphorus and Potassium uptake (Kg $\mathrm{ha}^{-1}$ ) in SRI cultivation.

\begin{tabular}{|c|c|c|c|c|c|c|c|c|c|c|c|c|}
\hline \multirow{2}{*}{$\begin{array}{c}\text { Fertilizer } \\
\text { schedule } \\
\text { Treatment } \\
\text { No. }\end{array}$} & \multicolumn{4}{|c|}{ Nitrogen } & \multicolumn{4}{|c|}{ Phosphorus } & \multicolumn{4}{|c|}{ Potassium } \\
\hline & $F_{1}$ & $F_{2}$ & $\mathbf{F}_{3}$ & Mean & $F_{1}$ & $\mathbf{F}_{2}$ & $F_{3}$ & Mean & $F_{1}$ & $\mathbf{F}_{2}$ & $\mathbf{F}_{3}$ & Mean \\
\hline$\overline{T_{1}}$ & 47.4 & 48.8 & 49.6 & 48.6 & 9.6 & 9.8 & 10.1 & 9.8 & 12.7 & 12.9 & 13.0 & 12.9 \\
\hline $\mathrm{T}_{2}$ & 50.3 & 53.2 & 54.0 & 52.5 & 12.0 & 13 & 14.2 & 13.0 & 13.3 & 13.6 & 14.0 & 13.6 \\
\hline $\mathrm{T}_{3}$ & 51.6 & 58.0 & 58.5 & 56.0 & 13.0 & 13.6 & 14.3 & 13.6 & 13.3 & 13.9 & 14.2 & 13.8 \\
\hline $\mathrm{T}_{4}$ & 52.5 & 61.3 & 61.6 & 58.4 & 13.6 & 16.9 & 14.4 & 16.9 & 13.6 & 14.0 & 14.2 & 13.9 \\
\hline $\mathrm{T}_{5}$ & 53.0 & 62.0 & 62.6 & 59.5 & 14.2 & 14.1 & 15.6 & 14.6 & 13.7 & 14.2 & 14.5 & 14.1 \\
\hline \multirow[t]{2}{*}{ Mean } & 50.9 & 56.6 & 57.1 & 55.0 & 12.1 & 12.8 & 13.7 & 13.0 & 13.3 & 13.7 & 14.0 & 13.7 \\
\hline & $\mathrm{SE}_{\mathrm{D}}$ & & \multicolumn{2}{|c|}{$\mathrm{CD}(\mathrm{P}=0.05)$} & \multicolumn{2}{|l|}{$\mathrm{SE}_{\mathrm{D}}$} & \multicolumn{2}{|c|}{$\mathrm{CD}(\mathrm{P}=0.05)$} & \multicolumn{2}{|l|}{$\mathrm{SE}_{\mathrm{D}}$} & \multicolumn{2}{|c|}{$\mathrm{CD}(\mathrm{P}=0.05)$} \\
\hline $\mathrm{F}$ & \multicolumn{2}{|c|}{0.26} & \multicolumn{2}{|c|}{0.54} & \multicolumn{2}{|c|}{0.14} & \multicolumn{2}{|c|}{0.29} & \multicolumn{2}{|c|}{0.04} & & 0.10 \\
\hline $\mathrm{T}$ & \multicolumn{2}{|c|}{0.34} & \multirow{2}{*}{\multicolumn{2}{|c|}{0.69}} & \multicolumn{2}{|c|}{0.18} & \multicolumn{2}{|c|}{0.38} & \multicolumn{2}{|c|}{0.06} & & 0.13 \\
\hline $\mathrm{F} \times \mathrm{T}$ & \multicolumn{2}{|c|}{0.59} & & & \multicolumn{2}{|c|}{0.32} & \multicolumn{2}{|c|}{0.66} & \multicolumn{2}{|c|}{0.11} & & 0.22 \\
\hline
\end{tabular}

F: Factors; T: Treatments

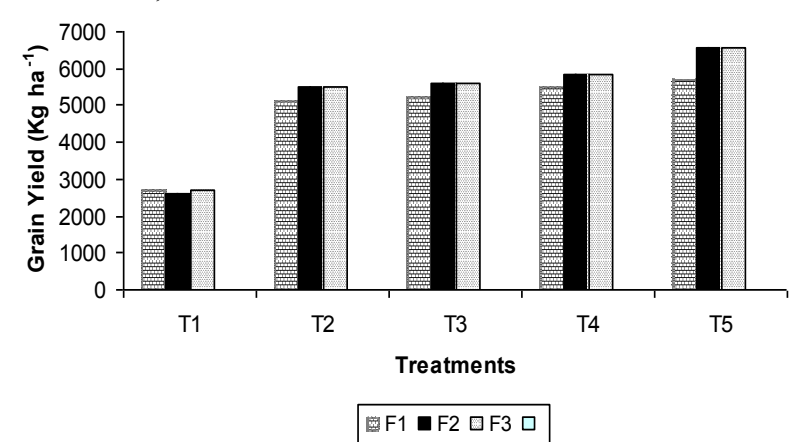

Fig. 1. Effect of graded levels and timing of nitrogen and potassium application on grain yield $\left(\mathrm{kg} \mathrm{ha}^{-1}\right)$ in SRI cultivation. (Field experiment $-I$ ).

recommended dose of fertilizer schedule applied with time interval based on soil nutrient. It helps to increase the fertilizer use efficiency (FUE) and improve crop yield. In soils where the initial status of $\mathrm{K}$ is high, skipping of basal $\mathrm{K}_{2} \mathrm{O}$ and application of $33.3 \% \mathrm{~K}_{2} \mathrm{O}$ each at 15,30 and 45 DAT with recommended fertilizer dose of $\mathrm{N}, \mathrm{P}$ and $\mathrm{K}_{2} \mathrm{O}$ 150:38:47.5 $\mathrm{kgha}^{-1}$ can

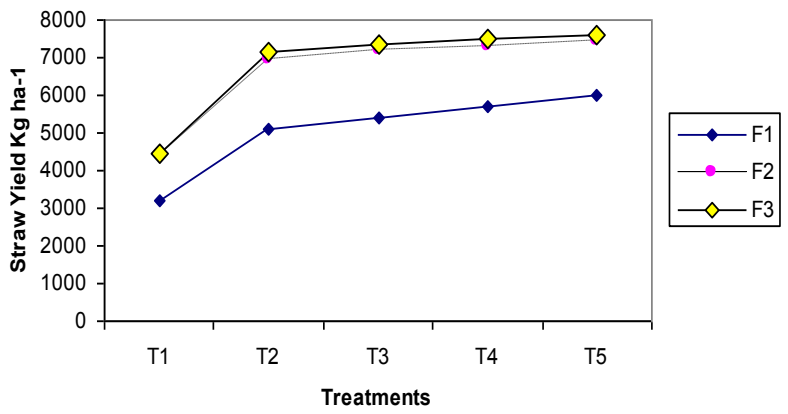

Fig. 2. Effect of graded levels and timing of nitrogen and potassium application on straw yield $\left(\mathrm{kg} \mathrm{ha}^{-1}\right)$ in SRI cultivation. (Field experiment $-I$ ).

be recommended under SRI cultivation to the farming community.

\section{REFERENCES}

Ali, A.M.S. Zia, F. Hussain, M. Salim, I.A. Mahmood and A. Shahzad (2005). Efficacy of different methods of potassium fertilizer application on paddy yield, $\mathrm{K}$ up- 
take and agronomic efficiency. Pakistan J. Agri. Sci. 42 (1-2): 27-32.

Arivazhagan, K. (1999). Nitrogen and Potassium interaction in rice. Ph.D. Thesis Dissertation submitted to Faculty of agriculture, Annamalai Univ., Annamalainagar, Chidmbaram.

Arivazhagan, K. and Ravichandran M., (2005). Interaction of nitrogen and potassium on yield and yield attributes in rice Cv. IR 20.Ad. Plant Sci., 18: 425-427.

Cassman, K.G.A. Doberman and D.T. Walter. (2002). Agroecosystems, nitrogen-use efficiency, and nitrogen management. AMBIO: A Journal of the Human Environment, 31, 6497-6517.

Awan, T.H.; Z. Manzoor; M.E. Safdar and M. Ahmad. (2007). Yield response of rice to dynamic use of potassium in traditional rice growing area of Punjab. Pakistan J. Agri. Sci.., 44 (1): 130-135.

FAO (2003). htt://fao.org/English/df/2003/IYR110. htm accessed on $3 / 25 / 2006$.

IASRI / ICAR (2003). Agricultural research data book, Indian council of Agricultural Research, New Delhi.

Juanita, S. (2007). Effect of timing and levels of potassium in SRI cultivation. M.Sc. (Ag.). Thesis, submitted to Annamalai University, Chidmbaram.

Ju, X.T. Xing, G.X., Zang. S.L., Zhang. L.J., Liu., X.J. Cui, Z.I., Yin, B., Christie, P., Zhu, Z.L. Zhang, F.S. (2009). Redusing environmental risk by improving $\mathrm{N}$ management in intensive Chanese agricultural systems. Proc. Natl. Acad. Sci. USA. 106:3041-3046.

Majumdar, S.K. and Ghosh, D.C. (1980). Effect of split application of potash on yield of high yielding rice. (Pusa 2-21). Indian potash J., 5(3): 8-10.

Manzoor,Z. , T.H. Awan, M. Ahmad, M. Akhter and F.A. Faiz. (2008). Effect of split pplication of potash on yield and yield related traits of basmati rice. J. Anim. Pl. Sci. 18(4): 120-124

.Marschner, H. (1995). Mineral nutrition of higher plants. $2^{\text {nd }}$ Ed. Academic Press, San Diego, New York.

Mengel, K. (2007). Potassium. In: Barker A.V., Pilbeam D.J., editors, Handbook of plant nutrition. Boca Raton (FL): CRC press. P. 91-121.

Mondal, S.S, Jayaram, D, Pradban, B.K. and Das, S.K. (1989). Rate, time and pattern of application of nitrogen and potassium in influencing the yield compo- nents and yield of rice. J. Pot. Res., 5: 77- 81.

Radha Kumar, C. and Srinivasulu Reddy, D. (2009). Performance of Rice Under Crop Reside Incorporation and Different Nitrogen Management Practices. Madras Agric. J., 96(7-12): 365-369.

Raun, W.E., Solie, J.B., Johnson, G.V., Stone, M.L., Mullen, R.W., Freeman, K/W.,Thomason, W.E., Lukina, E.V., (2002). Improving nitrogen use efficiency in cereal grain production with optical sesing and variable rate application. Agron. J. 94, 815-820.

Ravichandran, M. and M.V. Iramach and Rasekharan (2011). Optimizing timing of potassium application in productivity enhancement of crops. Karnataka J. Agric. Sci.,24 (1) : (75-80).

Samrathlal, M., S. Surendra and Y.S. Shivay (2003). Response of hybrid rice (Oryza Sativa) to nitrogen and potassium application in sandy clay-loam soils. Indian J. of Agri. Sci. 73(1): 8-11.

Shanhan, J.F. Kitchen, N.R, Raun and W.R, Schepers J.S. (2008). Responsive in-season nitrogen management for cereals. Computers and Electronics in Agriculture, 61, 51-62.

Singh, S.P., Suppaiah, S.V. and Kumar, R.M. (2006). Response of rice Varieties to nitrogen application time under direct seeded puddle condition. Oryza, 43:157-158.

Stoop, N.A, Uphoff, N., Kassam, A. (2002). A review of agricultural research issues raised by the System of Rice Intensification (SRI) from Madagascar: Opportunities for improving farming system for resousce-poor farmers. Agric. Syst. 71: 249-274.

Stoop, W.A. (2003). The system of rice intensification (SRI) from Madagascar; myth or missed opportunity? Report on study visit to the "Hauts Plateaux" region of Madagascar (3-15 march 2003). Stoop. Consult, Direbergen- R., The Netherlands, 17 pp.

Uphoff, N, Fernandes, E, Yuan, L.P, Peng, J, Rafaralahy, S. and Rabenandrasana. J. (2002). Assessments of the system of rice intensification (SRI). Proc. Intern. Conf. Sanya, China, April 1-4.

Venkitasamy, R, Sridharan, C.S, Madhiyazhagan, R. and Prabhakaran, N.K. (1997). Split application of nitrogen and potassium in MaR hybrid rice. Madras Agric. $J, 84(1): 43-44$. 